\title{
Peningkatan Prestasi dan Aktifitas Siswa Melalui Metode Pembelajaran Tutor Sebaya Pada Materi Pelajaran Pengujian Mutu Hasil Perikanan Kelas 3 Semester 6 Program Studi TPHP di SUPM N Sorong
}

\author{
Budi Satriyanto \\ Sekolah Usaha Perikanan Menengah (SUPM) Sorong \\ budisatriyanto100174@gmail.com
}

\begin{abstract}
Abstrak : Penelitian bertujuan untuk meningkatkan keaktifan dan hasil belajarar peserta didik pada mata pelajaran pengujian Mutu Hasil Perikanan Kelas 3 Semester 6 Program Studi TPHP di SUPM Sorong, melalui penerapan metode Tutor Sebaya. Subyek penelitian peserta didik kelas 3 TPHP Semester 6 Tahun Pelajaran 2019/2020 dengan jumlah peserta didik 26 orang. Penelitian yang dilakukan terdiri dari dua siklus dan setiap siklus dengan tiga kali pertemuan setiap siklusnya dan sebelum siklus I dilakukan terlebih dahulu dilakukan Pra-siklus. Teknik pengumpulan data menggunakan observasi, tes hasil belajar, dan dokumentasi. Teknik analisis data menggunakan deskriptif kuantitatif. Dari hasil Penelitian Tindakan Kelas (PTK) menunjukan bahwa penerapan metode pembelajaran Tutor Sebaya pada mata pelajaran Pengujian Mutu Hasil Perikanan dapat meningkatkan keaktifan dan hasil belajar peserta didik kelas 3 semester 6 Program Studi TPHP. Rata-rata persentase keaktifan belajar peserta didik pada siklus I sebesar $53 \%$, mengalami peningkatan pada siklus II menjadi $74 \%$. Peningkatan keaktifan belajara siswa terdapat pada indikator memperhatikan penjelasan materi dari guru, mendengarkan penjelasan materi dari guru, memperhatikan penjelasan materi dari Tutor Sebaya, mendengarkan penjelasan materi dari Tutor Sebaya dan membuat catatan materi.
\end{abstract}

Kata kunci : PTK; Tutor Sebaya; Keaktifan Peserta Didik; Hasil Belajar; Pengujian Mutu Hasil Perikanan.

Abstract: This study aims to increase the activeness and learning outcomes of students in the subject of testing the quality of fisheries products in Grade 3 Semester 6 of the TPHP Study Program in SUPM Sorong, through the application of the Peer Tutor method. The research subjects of Class 3 TPHP Semester 6 Academic Year 2019/2020 with 26 students. This research consisted of two cycles and each cycle with three meetings each cycle and before the first cycle was carried out a pre-cycle was carried out. Data collection techniques using observation, test learning result, and documentation. The data analysis technique used quantitative descriptive. The results of the Classroom Action Research (CAR) show that the application of the Peer Tutor learning method in the Fishery Product Quality Testing subject can increase the activeness and learning result of grade 3 students in semester 6 of the TPHP Study Program. The average percentage of students' learning activeness in the first cycle was 53\%, an increase in the second cycle to $74 \%$. The increase in student learning activeness is in the indicators of paying attention to material explanations from the teacher, listening to material explanations from the teacher, paying attention to material explanations from Peer Tutors, listening to material explanations from Peer Tutors and making material notes.

Keywords: CAR; Peer Tutor; Student Activity; Learning Result; Fishery Product Quality Testing.

\section{Pendahuluan}

Proses belajar mengajar merupakan satu rangkaian yang saling terkait dan tidak dapat dipisahkan. Kegiatan pembelajaran yang dilakukan guru merupakan salah satu penentu keberhasilan proses belajar peserta didik. Peserta didik akan belajar lebih baik dan bermakna apabila kegiatan pembelajaran yang dipilih oleh guru relevan dan mendukung aktivitas belajar. Kegiatan belajar 
mengajar sudah selayaknya berfokus pada peserta didik yang belajar (student oriented) bukan peran guru yang dominan. Hal ini perlu sama-sama disadari oleh kedua belah pihak baik guru maupun peserta didik, guru hanya berpihak sebagai fasilitator dalam kegiatan belajar mengajar yang bertugas membuat desain pembelajaran sedangkan peserta didik merupakan subjek belajar yang harus benar-benar aktif dan sungguh-sungguh mengikuti kegiatan belajar mengajar.

Berdasarkan pengamatan pada saat melaksanakan Penelitian Tindakan Kelas (PTK) selama 3 (tiga) bulan, yaitu pada bulan Februari sampai dengan bulan April 2020 dan pada saat observasi pada tanggal 15 April 2020, diperoleh gambaran proses pembelajaran dan kondisi siswa pada saat proses belajar berlangsung. Metode pembelajaran yang digunakan masih metode konvensional yang salah satunya ialah metode demonstrasi. Awal pembelajaran demonstrasi dapat menarik perhatian peserta didik, namun semakin lama peserta didik merasa bosan dan ngantuk. Metode tannya jawab yang diterapkan pun belum berjalan secara efektif, hanya sedikit peserta didik yang mau bertannya mengenai materi pembelajaran yang belum dipahami. Pelaksanaan praktikum pun banyak peserta didik menemui kesulitan, dan hanya sedikit yang mau bertanya kepada guru maupun teman. Data nilai ulangan harian pada Mata Pelajaran Pengujian Mutu Hasil Perikanan peserta didik menunjukan persentase ketuntasan peserta didik sebesar $42 \%$. Hal tersebut menujukan bahwa keaktifan peserta didik dalam proses pembelajaran perlu ditingkatkan lagi agar hasil belajar peserta didik pun dapat meningkat.

Pembelajaran perlu dilakukan dengan metode-metode yang menekankan interaksi antar peserta didik. Penggunaan metode yang bervariasi akan sangat membantu peserta didik dalam mencapai tujuan pembelajaran. Berdasarkan permasalahan-permasalahan yang telah diuraikan diatas yaitu diantaranya terdapat beberapa peserta didik yang saling membantu ketika menemukan kesulitan, dan beberapa peserta didik lebih memilih bertanya kepada teman sebaya ketika ada materi yang belum dipahami dibandingkan dengan bertannya kepada guru, dan materi pembelajaran yang disampaikan lebih banyak praktikum daripada teori, maka salah satu alternative cara yang dapat digunakan sebagai usaha meningkatkan keaktifan dan hasil belajar peserta didik adalah dengan menerapkan metode pembelajaran tutor sebaya. Metode tutor sebaya ialah metode belajar yang memanfaatkan teman sebagai tutor dalam proses belajar mengajar. Peserta didik dibagi memjadi beberapa kelompok, dan setiap kelompok terdapat tutor sebaya. Metode pembelajaran Tutor Sebaya adalah salah satu dari berbagai metode pembelajaran yang sangat membutuhkan peran aktif peserta didik.

Ada beberapa diaognosis permasalahan yang biasa terjadi di kelas seperti pelaksanaan Kurikulum 2013 Edisi Revisi belum dilaksanakan secara maksimal karena metode pembelajaran yang digunakan belum menekankan pada interaksi antar peserta didik, metode pembelajaran yang digunakan masih bersifat monoton sehingga membuat peserta didik cepat merasa bosan, Keaktifan belajar peserta didik perlu ditingkatkan karena peserat didik yang belum memahami materi pembelajaran cenderung diam sehingga berdampak pada hasil belajar, Hasil belajar siswa perlu ditingkatkan karena persentase ketuntasan nilai ulangan harian peserta didik hanya mencapa $42 \%$.

Berdasarkan latar belakang dan identifikasi masalah yang telah diuraikan, fokus permasalahan pada Penelitian Tindakan Kelas (PTK) ini kurangnya keaktifan belajar peserta didik dalam pembelajaran sehingga berdampak pada rendahnya hasil belajar peserta didik, dan metode pembelajaran Tutor Sebaya belum pernah diterapkan pada Mata Pelajaran Pengujian Mutu Hasil Perikanan dengan tujuan yang ingin dicapai dalam penelitian ini agar dapat meningkatkan keaktifan dan meningkatkan hasil belajar peserta didik pada mata pelajaran pengujian mutu hasil perikanan kelas 3 di SUPM N Sorong melalui penerapan metode belajar Tutor Sebaya.

\section{Metode Penelitian}

Menurut Rustam dan Mundilarto (2004:1) “ Penelitian Tindakan Kelas (PTK) adalah sebuah penelitian yang dilakukan oleh guru di kelasnya sendiri dengan jalan merancang, melaksanakan dan 
merefleksikan tindakan secara kolaboratif dan partisipatif dengan tujuan untuk memeperbaiki kinerja sebagai guru sehingga hasil belajar siswa dapat meningkat".

Metode pembelajaran tutor sebaya menurut Depdiknas dalam Majid (2013:206) merupakan kegiatan pembelajaran yang dilakukan seorang peserta didik kepada siswa lainnya dan salah satu siswa itu lebih memahami materi pembelajaran. Tutor dalam pembelajaran tutor sebaya adalah siswa yang sebaya yang ditunjukan atau ditugaskan membantu temannya yang mengalami kesulitan belajar, karena hubungan antara teman umumnya lebih dekat dibandingkan hubungan guru dengan siswa (Ahmadi dan Supriyono, 1991:173), dan menurut Makarao (2009:127) Tutor Sebaya adalah metode pelatihan yang memfasilitasi peserta untuk mengajarkan suatu pengetahuan atau keterampilan tertentu kepada sesame peserta lainnya.

Inti dari metode tutor sebaya (peer tutoring) adalah guru memberdayakan siswa yang mempunyai daya serap tinggi terhadap materi yang dijelaskan guru untuk membantu siswa lain yang daya serapnya rendah. Siswa yang berperan sebagai tutor terlebih dahulu dibekali oleh materi yang akan dibahas dalam kegiatan belajar mengajar yaitu materi Pengujian Mutu Hasil Perikanan. Pembekalan ini dapat dilakukan di luar maupun di dalam jam pelajaran. Peserta didik yang berperan sebagai tutor bertugas membantu temannya yang mengalami kesulitan melalui proses diskusi setelah mendapatkan pembekalan dari guru mengajar. Peran guru dalam proses ini adalah mengawasi kelancaran pelaksanaan metode dengan mengamati, mencatat perkembangan proses, memberikan pengarahan serta evaluasi proses untuk selanjutnya digunakan bimbingan dan membahas soal yang berhubungan dengan materi yang diajarkan.

Analisa data terhadap tes hasil belajar peserta didik dilakukan analisis kuantitatif dengan menentekan rat-rata nilai tes diperoleh dari penjumlahan nilai yang diperoleh peserta didik, selanjudnya dibagi dengan jumlah peserta didik yang ada didalam kelas tersebut. Pemberian skor tes didasarkan pada jumlah skor jawaban yang benar pada saat evaluasi. Angka skor yang digunakan dari skala 0 sampai skala maksimal 100. Menurut Sudjiman (2014:109) untuk menghitung rata-rata hasil tes dapat digunakan rumus sebagai berikut:

Keterangan :



$\mathrm{X}=$ Nilai rata-rata

$\sum \mathrm{X}=$ Jumlah semua nilai siswa

$\sum \mathrm{N}=$ jumlah siswa

Sedangkan rumus yang digunakan dalam menghitung persentase jumlah peserta didik yang dapat mencapai nilai $\geq 75$ adalah sebagai berikut :

$$
\mathrm{P}=\frac{\sum n i}{\sum n o} \times 100 \%
$$

Keterangan :

$\mathrm{P}=$ Presentase ketuntasan Siswa $\geq 75$

$\sum$ ni $=$ Jumlah siswa yang mencapai $\geq 75$

$\sum$ no $=$ Jumlah seluruh siswa

\section{Hasil dan Pembahasan}

Pelaksanaan Penelitian Tindakan Kelas (PTK) di SUPM N Sorong dilaksanakan pada bulan Februari sampai dengan April 2020. Sebelum penelitian dilaksanakan, perlu adanya kegiatan pra tindakan ini berupa opservasi mengenai keadaan proses pembelajaran di kelas. Observasi dilakukan secara langsung dengan mengamati proses kegiatan belajar mata pelajaran Pengujian Mutu Hasil Perikanan, dikelas III TPHP semester 6 dengan jumlah peserta didik sebanyak 26 peserta didik. 
Berdasarkan hasil observasi diperoleh hasil bahwa tingkat keaktifan peserta didik dalam mengikuti pelajaran masih kurang, dan hal ini berdampak pada pencapaian hasil belajar peserta didik.

Berdasarkan nilai post test ulangan harian mata pelajaran Pengujian Mutu Hasil Perikanan di atas, dapat diketahui bahwa tes hasil belajar kognitif peserta didik pada salah satu materi menunjukan presentase ketuntasan peserta didik dengan nilai lebih atau sama dengan KKM sebesar $31 \%$ yaitu dengan jumlah 26 peserta didik. Sedangkan hampir separuh dari jumlah keseluruhan peserta didik kelas III TPHP mendapat nilai dibawah KKM. Aspek psikomotorik, hasil penelitian unjuk kerja siswa menunjukan persentase ketuntasan sebesar 31\%. Hal tersebut menunjukan bahwa hasil belajar peserta didik kelas III TPHP masih kurang.

Diketahui bahwa presentase ketuntasan hasil belajar peserta didik pada pra siklus mencapai $51,61 \%$. Pada siklus I yang membahas mengenai pengujian Idol presentase ketuntasan hasil belajar kognitif peserta didik sebesar 58\% dengan rata-rata kelas sebesar 71 Sedangkan pada aspek psikomotorik, hasil penilaian unjuk kerja peserta didik pada siklus I memperoleh persentase ketuntasan sebesar 58\% dengan rata-rata kelas sebesar 71.

Siklus II yang membahas materi mengenai Pengujian kadar Histamin memperoleh persentase ketuntasan hasil belajar kognitif peserta didik sebesar $81 \%$ dengan rata-rata kelas 79 sedangkan pada aspek psikomotorik, hasil penilaian unjuk kerja peserta didik pada siklus II memperoleh persentase ketuntasan sebesar $85 \%$ dengan rata-rata kelas sebesar 79.2.

Persentase ketuntasan hasil belajar kognitif peserta didik pada pra siklus sebesar $31 \%$. peningkatan terjadi dari pra siklus I ke siklus I sebesar 17\%. Aspek psikomotorik, pada pra siklus memperoleh persentase ketuntasan peserta didik sebesar 31.\%. peningkatan ketuntasan penilaian pada aspek psikomotorik terjadi pada pra siklus ke siklus I sebesar $27 \%$, persentase ketuntasan hasil penilaian unjuk kerja mengalami peningkatan kembali pada siklus I ke siklus II sebesar $27 \%$.

Berdasarkan hasil pemaparan data hasil penilaian di atas, maka dengan diterapkannya metode pembelajaran Tutor Sebaya dapat meningkatkan hasil belajar peserta didik. Hasil belajar peserta didik dari pra siklus ke siklus I maupun siklus II semakin baik, salah satunya iyalah proses adaptasi dan materi yang disampaikan untuk tiap siklus berbeda. Siklus I peserta didik belum secara penuh beradaptasi menerapkan metode pembelajaran yang diterapkan. Himbauan dari guru pada saat proses belajar mengajar berlangsung agar peserta didik lebih aktif berdiskusi sevcara serius karena sebagian besar materi disampaikan oleh tutor sebaya.

\section{Kesimpulan dan Saran}

Berdasarkan penelitian yang telah dilaksanakan, dapat dilihat bahwa penerapan metode pembelajaran Tutor Sebaya terbukti dapat meningkatkan keaktifan dan hasil belajar peserta didik. Hal tersebut dapat dilihat pada data hasil pengamatan yang menunjukan adanya peningkatan keaktifan belajar peserta didik pada setiap pertemuan, serta terjadinya peningkatan hasil belajar peserta didik dengan ketuntasan belajar lebih dari atau sama dengan KKM pada setiap siklusnya. Oleh karena itu, metode pembelajaran Tutor Sebaya dapat diterapkan oleh guru sebagai variasi dalam kegiatan pembelajaran. Hal tersebut untuk mewujudkan harapan terjadinya peningkatan kualitas dan hasil transfer pengetahuan dalam rangka perbaikan pembelajaran kearah yang lebih baik.

Adapun saran yang dapat disampaikan ialah ; Keaktifan belajar peserta didik perlu ditingkatkan lagi pada indikator berani memjawab pertannyaan guru, berani menjawab pertannyaan dari teman, dan menuliskan peranyaan pada lembar pertannyaan, karena persentase yang diperoleh masih kurang. Meskipun sudah memnuhi target yang ditentukan. Pemilihan tutor sebaya tidak hanya melihat nilai akdemik tetapi juga perlu memperhatikan keaktifan belajar dan sikapnya. 


\section{Daftar Pustaka}

Ahmadi, A \& Widodo S. (1991). Psikologi Belajar. Jakarta: Rineke Cipta.

Arifin, Zainal. 2010. Evaluasi Pembelajaran. Bandung : PT. Remaja Rosdakarya

Daryanto \& Syaiful Karim. (2017). Pembelajaran Abad 21. Yogyakarta: Penerbit Gava Media

Djamarah, S.B. \& Aswan Z., (2013). Strategi Belajar Mengajar. Jakarta: Rineke Cipta

Hasriani. 2003. Peningkatan Hasil Belajar Matematika melalui model pembelajaran cooperative learning dengan pendekatan STAD pada siswa kelas IIA SLTP Negeri 21 Makassar. Skripsi Jurusan Matematika FMIPA UNM. Makassar.

Haling, Abdul. 2007. Belajar dan Pembelajaran. Makassar. UMN.

Hamalik, O. (2013). Proses Belajar Mengajar. Jakarta: PT Bumi Askara.

Hamdayana,J. (2016). Metodologi Pengajaran. Jakarta: PT Bumi Aksara

Kurniasih, I. \& Berlin S. (2014). Revisi Kurikulum 2013 Implementasi Konsep dan Penerapan. Surabaya: Kata Pena.

Majid, A. (2013). Strategi Pembelajaran. Bandung: PT Remaja Rosdakarya

Makarao, N.R. (2009). Metode Mengajar Dalam Bidang Kesehatan. Bandung: Alfabeta.

Mulyaningsih, E. (2011). Riset Terapan Bidang Pendidikan dan Teknik. Yogyakarta: UNY PRESS.

Rochayati, U. \& Masduki Z. (2010). Peningkatan Kualitas Pembelajaran Teknik Digital Melalui Pembelajaran Berbasis Lesson Study. Yogyakarta: Jurnal Pendidikan Teknologi dan Kejuruan, Volume 19 Nomor I. Hlm 26-27.

Slameto. 2003. Belajar dan Faktor-faktor yang Mempengaruhi. Jakarta : Rineka Cipta

Sardiman, (2016). Interaksi dan Motivasi Belajar Mengajar. Jakarta: Raja Grafindo

Schunk, D.H. (2012). Learning Theories: An Education Perspective (Teori-teori Pembelajaran: Perspektif Pendidikan Edisi Keenam). Diterjamahkan oleh: Eva Hamdiah, Rahmad Fajar. Yogyakarta: Pustaka Pelajar.

Siregar, E. \& Hartini N. (2014). Teori Belajar dan Pembelajaran. Bogor: Ghalia Indonesia

Sudjana, N. (2005). Metode \& Teknik Pembelajaran Partisipatif. Bandung: Falah Production.

Uno, Hamzah B. \& Nurdin Muhammad. (2013). Belajar dengan Pendekatan PAIKEM. Jakarta: PT Bumi Aksara. 